\title{
Unusual metabolites from some Tanzanian indigenous plant species*
}

\author{
Mayunga H. H. Nkunya \\ Department of Chemistry, University of Dar es Salaam, P.O. Box 35061, Dar es \\ Salaam, Tanzania
}

\begin{abstract}
In this paper, the chemistry of some unusual natural products that were isolated from various Tanzanian indigenous plant species during the past 20 years is reviewed. Among the compounds covered in this review are cyclohexane epoxides; heptane derivatives; oxygenated pyrenes; phenanthrene derivatives; flavonoids with uncommon structural frameworks; mono-, bis-, and dimeric prenylated indoles; and variously substituted mono-, sesqui-, and diterpenoids.
\end{abstract}

Keywords: Heptane derivatives; cyclohexane epoxides; flavonoids; indoles; phenanthrenes; terpenoids; antimalarial activities; Uvaria species; Annonaceae species.

\section{INTRODUCTION}

Tanzania is endowed with a great abundance of floral diversity, which is estimated to constitute about 10000 vascular plant species, of which at least $25 \%$ are considered to be indigenous to the country and among them, about 1200 species so far have been reported to occur exclusively in Tanzania [1]. Although some of the plant species are used as herbal remedies and for other applications, not many studies have been carried out to unravel the chemical constituents of some of the Tanzania plant species, particularly those that are considered to be restricted to this country, some of which have been taxonomically described only recently [2-6]. Therefore, in 1984, we initiated chemical investigations for novel and/or biologically active natural products from Tanzanian plant species that are either deployed in traditional medicines, used as natural insecticides, rare species, or those that are threatened with extinction due to among others, human developmental activities. In these investigations, over the years we have isolated a number of compounds with unusual chemical structures, some of which also possessed antimalarial, antitrypanosomal, antibacterial, antifungal, and cytotoxic activities. Some of the isolated natural products are classifiable in the following broad structural categories:

- Cyclohexane epoxides and heptane derivatives

- $\quad$ Flavonoids with uncommon structural frameworks

- $\quad$ Oxygenated pyrenes and phenanthrene derivatives

- $\quad$ Mono- and dimeric prenylated indoles

- Variously substituted mono-, sesqui-, and diterpenoids

This paper reviews our investigations for natural products from some Tanzanian indigenous plant species during the past 20 years, some of the compounds having unusual chemical structures.

\footnotetext{
*Paper based on a presentation at the $9^{\text {th }}$ International Chemistry Conference in Africa (ICCA-9), Arusha, Tanzania, 2-7 August 2004. Other presentations are published in this issue, pp. 1923-1964.

¥Corresponding author: E-mail: Nkunya@chem.udsm.ac.tz
} 


\section{CYCLOHEXANE EPOXIDES}

Cyclohexane epoxides containing a benzoyloxymethylene unit have been isolated from Tanzanian Annonaceae species that are found in coastal forests near Dar es Salaam. Similar compounds have also been obtained from Annonaceae species occurring in Madagascar and South East Asia. Most of the compounds have broad spectra of biological activities, and for this reason, this small group of natural products has attracted considerable research interest and some of its members have even been synthesized. Thus, during the past 36 years, several oxygenated cyclohexane epoxides have been obtained from African and South East Asian Uvaria species, which in Africa include U. catocarpa from Madagascar [7], and $U$. pandensis, $U$. faulknarae, and $U$. dependens from Tanzania [8,9]. The natural products have also been obtained from the Annonaceae species, Monanthotaxis species [10], Friesodielsia obovata [11], and Cleistochlamys kirkii [12], as well as from Zingiberaceae [13] and Euphorbiaceae [14] species, thereby suggesting a (chemo) taxonomical relationship between the Annonaceae and the latter two plant families.

In 1978, we reported notable antibacterial activity of extracts from Uvaria accuminata [15], and in 1991 we demonstrated antimalarial activities of several Tanzania Uvaria species [16]. This inspired us to carry out extensive investigations of Uvaria species occurring in Tanzania for compounds that would be responsible for the observed biological activities. Initially, we focused our investigations on the then not-yet taxonomically described Uvaria species occurring in coastal forests near Dar es Salaam, that was later named Uvaria pandensis Verdc. [4]. From this plant species, we isolated the cyclohexane epoxides (+)- $\beta$-senepoxide (1), (+)-pandoxide (2), and (-)-pipoxide (3) [8], the latter being an enantiomer of (+)-pipoxide (4), which was previously isolated from the South East Asian Uvaria species, viz. $U$. purpurea [17]. Indeed, the occurrence in nature of the enantiomeric epoxides (-)-pipoxide (3) and (+)-pipoxide (4) facilitated confirmation of the biosynthetic proposal that was previously postulated for the formation of cyclohexane epoxides occurring in Uvaria species, based on the highly unstable arene oxide that would be formed from shikimic acid as the biosynthetic precursor $[13,18,19]$ (Scheme 1). Since then, (-)-pipoxide has been isolated from another Tanzanian Uvaria species, viz. $U$. dependens [9] and from Boesenbergia species (Zingiberaceae) [13].

It is interesting to note that the two sets of enantimeric pairs of cyclohexane epoxides $\mathbf{3}$ and $\mathbf{4}$, and 5 and $\mathbf{6}$ have already been isolated from Uvaria species [8,9,17,20,21], as previously predicted from the proposed biosynthesis of these compounds $[13,18,19]$. Thus, the biosynthetic proposal for polyoxygenated cyclohexane epoxides as shown in Scheme 1 envisions a nucleophilic $\beta$-arene oxide ring opening at C-3 through an $\alpha$ or $\beta$ attack leading to di-oxygenated cyclohexadienes 7 and 8 . Diastereoselective epoxidation of $\mathbf{7}$ and $\mathbf{8}$ would eventually form pairs of enantiomeric pipoxides $\mathbf{3}$ and $\mathbf{4}$, and $\mathbf{5}$ and $\mathbf{6}$, respectively. Indeed, cyclohexadiene intermediates related to $\mathbf{7}$ and $\mathbf{8}$ have already been isolated from Uvaria species, having been obtained from $U$. ferruginea, together with the corresponding epoxides $\beta$-(+)-senepoxide (1) and tingtanoxide (9) [20], thus giving further support to the biosynthetic proposal in Scheme 1.

It should be noted that the stereoisomeric epoxides $\mathbf{3}$ and $\mathbf{4}$ have a cis relationship between the epoxide ring and the oxygenated C-2 substituent, while for enantiomers $\mathbf{5}$ and $\mathbf{6}$ this relationship is trans. Correspondingly, the oxygenated C-2 and C-3 substituents in $\mathbf{3}$ and $\mathbf{4}$, and related compounds have a trans (coplanar) diequatorial stereochemical relationship, while those in $\mathbf{5}$ and $\mathbf{6}$, and related metabolites are trans axial/equatorial disposed. Therefore, in the ${ }^{1} \mathrm{HNMR}$ spectra, the $J_{2,3}$ value for epoxides having the relative stereochemistry as in $\mathbf{3}$ and $\mathbf{4}$ is larger (ca. $8.5 \mathrm{~Hz}$ ) than that for epoxides having the relative stereochemistry similar to 5 and $\mathbf{6}$ (ca. 2-3 Hz) $[7,8,20]$.

The cyclohexane epoxides 1-3 from $U$. pandensis exhibited antibacterial activity at different concentrations, with $(+)-\beta$-senepoxide being the most active. Furthermore, $(+)-\beta$-senepoxide, $(+)$-pandoxide, and (-)-pipoxide had a mild antimalarial activity against the multidrug-resistant strain $\mathrm{K} 1$ of Plasmodium falciparum malaria parasite in vitro [16], while in the antitumor tests against various human tumor cell lines, both (+)- $\beta$-senepoxide and (+)-pandoxide showed activity, with $(+)-\beta$-senepox- 


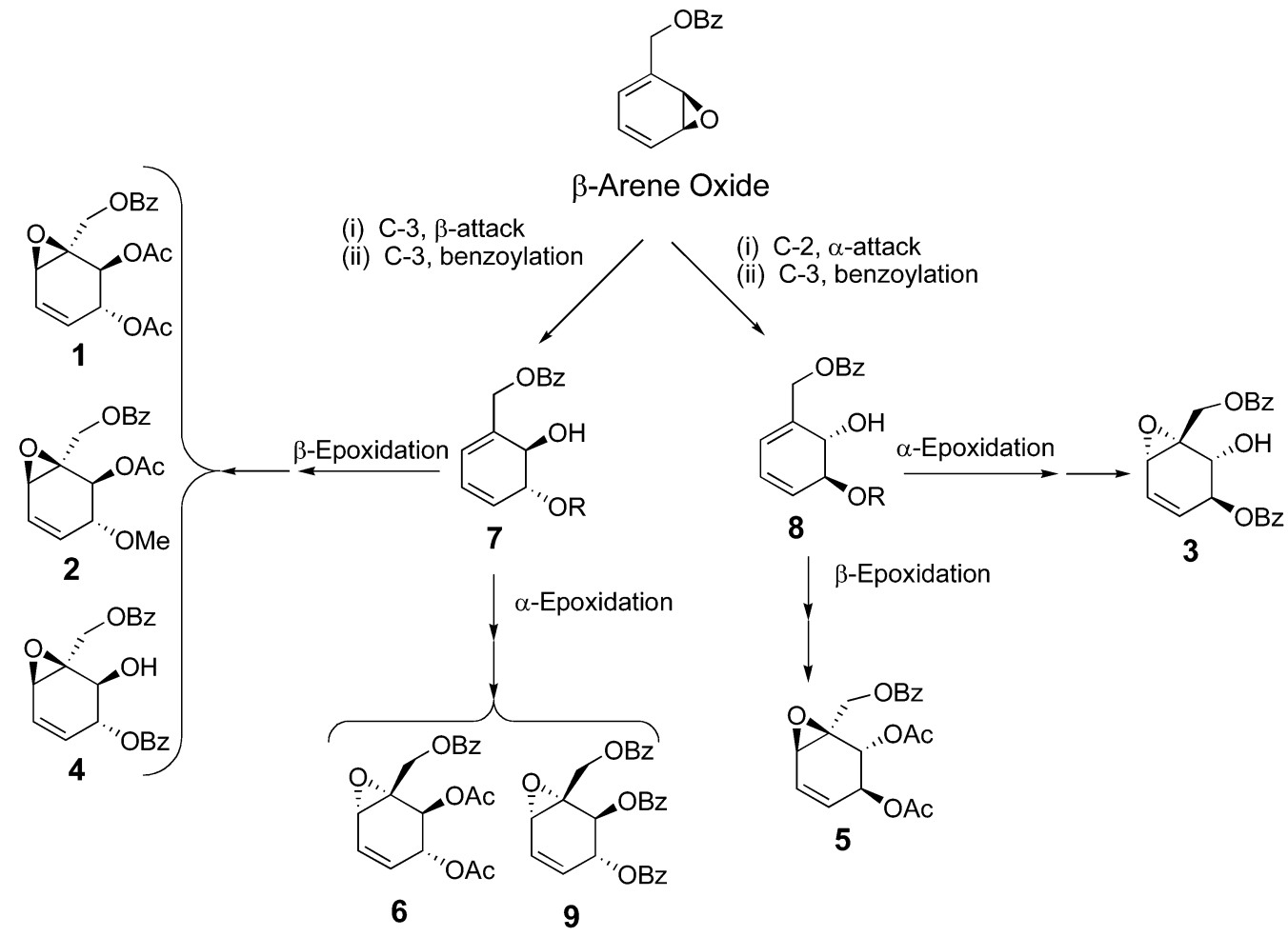

Scheme 1 Envisaged biosynthetic pathway for cyclohexane epoxides.

ide being more active than (+)-pandoxide. The biological activities of cyclohexane epoxides would expectedly result from the alkylating ability of the epoxide function, whose reactivity is enhanced by the presence of the double bond at the $\alpha, \beta$-position. Thus, based on this functionality, the cyclohexane epoxides can react with heterocyclic DNA base sites, either in parasite cells, tumor, or even healthy cells through nucleophilic or conjugate alkylation processes.

Because of the biological activities displayed by the cyclohexane epoxides, attempts have been made to synthesize the compounds. Thus, in the mid-1980s, Ogawa et al. elaborated a stereoselective synthesis of (+)-pipoxide and (+)- $\beta$-senepoxide [22]. Similarly, Ichihara et al. carried out several syntheses of cyclohexane epoxides employing a Diels-Alder cycloadditon reaction as the key step, whereby the intermediate cycloaddition products after being appropriately functionalized were transformed into the desired cyclohexane epoxides through retro Diels-Alder fragmentation processes [23].

\section{HEPTANE DERIVATIVES}

In the early 1990s, several oxygenated heptane derivatives having antitumor and/or other biological activities were isolated from South East Asian Sphaerocoryne (formally Melodorum) species [24,25]. Most of these compounds exhibited significant cytotoxicity against several tumor cell lines [24,25]. During our recent investigations of the Tanzanian Sphaerocoryne species, viz. S. gracilis ssp. gracilis we isolated the two cytotoxic heptane derivatives (+)-melodorinol (10) and (+)-acetylmelodorinol (11), together with the corresponding diol precursor (+)-5-(2,3-dihydroxy-propylidene)-5H-furan-2-one (12) [26] that was previously prepared from (+)-glyceraldehyde as an intermediate toward the synthesis of (+)-acetylmelodorinol [27]. More recently, another Annonaceae species, $C$. kirkii, yielded several heptenolides including (+)-acetylmelodorinol, (+)-5-(2,3-dihydroxy-propylidene)-5H-furan-2-one, and (+)-benzoylmelodorinol (13) [12,28,29]. 


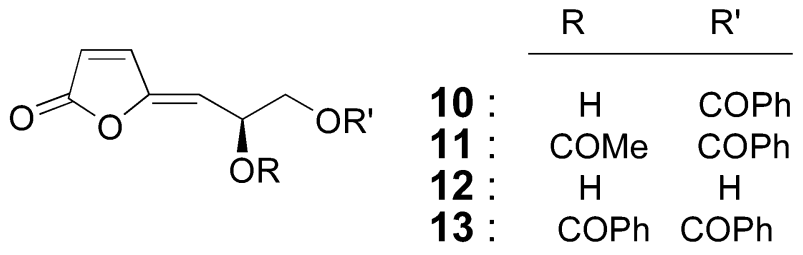

Chemically, both the naturally occurring cyclohexane and heptane derivatives have a seven-carbon molecular skeleton. As such, the compounds could be considered to have originated through similar biosynthetic processes. Thus, considering the already established biosynthetic pathway for cyclohexane derivatives involving shikimic acid as the biogenetic precursor, it may be reasonably assumed that just as shikimic acid, the heptane derivatives are similarly derived from photosynthetically formed erythrose 4-phosphate and phosphoenol pyruvate, whereby instead of undergoing enzymatically induced cyclization to form shikimic acid, the former precursor molecules would undergo coupling to form a heptose, which would ultimately be converted into a heptane derivative (Scheme 2).

PHOTOSYNTHESIS<smiles>O=C([O-])C1=CC(=O)C(O)[C@H](O)C1</smiles>

5-Dehydroshikimate<smiles>CC(=O)C1=C[C@@H](O)[C@H](O)[C@H](O)C1</smiles>

Shikimate<smiles>CCC(=O)[C@]1(O)CC(=O)C[C@@H](O)C1</smiles>

5-Dehydroquinate

Cyclohexane derivatives<smiles>O=C([O-])C(=O)CC(O)C(O)C(O)CO[PH]([O-])([O-])[O-]</smiles>

3-Deoxyarabinoheptulosonate-7-phosphate<smiles>[R]OCC([R])/C=C1\C=CC(=O)O1</smiles>

Heptane derivatives

Scheme 2 Proposed convergent biosynthesis of cyclohexane and heptane derivatives occurring in Annonaceae species.

\section{Oxygenated pyrenes and phenanthrene derivatives}

Pyrenes are not common among plant natural products, but these compounds are normally regarded as fossil oil products. However, we recently isolated the cytotoxic, oxygenated pyrenes 14 and 15 , and the 
phenanthrene derivative 6-hydroxy-3-methoxy-4-oxapyren-5-one (16) from Tanzanian Annonaceae species, namely Uvaria lucida ssp. lucida and U. puguensis, respectively [30,31]. Another phenanthrene derivative, 1,2-dihydro-2,9-dihydroxy-10-methoxyfuro[2,3-a]phenanthrene (17), was previously isolated from a Ghanaian Uvaria species, $U$. doeringii, together with the pyrenes 14 and 15, phenanthrene derivative $\mathbf{1 7}$ being considered to be the precursor of the two pyrenes, possibly involving an intermediate structure like 18 [30].<smiles>COc1c(O)cc2ccc3cc(O)c(OC)c4ccc1c2c34</smiles>

14<smiles>COc1ccc2ccc3ccc(O)c4c(=O)oc1c2c34</smiles>

16<smiles>COc1cc2ccc3cc(O)c(OC)c4ccc(c1OC)c2c34</smiles>

15<smiles></smiles><smiles>CCc1c(OC)cccc1-c1cc(OC)c(OC)cc1C</smiles>

\section{Less common flavonoids}

Several dihydrochalcones having antibacterial, antimalarial, and antitumor activities have been isolated from Annonaceae species occurring in Tanzania. The compounds contain one or two C-hydroxybenzyl groups on ring $\mathrm{A}$ and in some cases C-hydroxybenzyl units extending in a linear fashion. In many occasions, these compounds have been isolated as sets of positional isomers, such as uvaretin (19) and isouvaretin (20), diuvaretin (21), chamuvaritin (22) and angoluvarin (23), and triuvaretin (24) and isotriuvaretin (25) [31-33]. The corresponding flavanones chamanetin (26) and isochamanetin (27), dichamanetin (28), and uvarinol (29) and isouvarinol (30) have also been isolated from Annonaceae species $[26,30]$. The isomeric dihydrochalcones uvaretin and isouvaretin can be distinguished by considering the relative position of the ${ }^{1} \mathrm{H}$ NMR signal of the proton on the unsubstituted carbon on ring $\mathrm{A}$, which for uvaretin appears at higher field $(\delta$ 5.7-6.0) than in isouvaretin $(\delta \mathrm{ca} .6 .2)$ [33].

The ability of Annonaceae species to accumulate flavonoids with extended C-benzylation was again demonstrated by the isolation of a "tetrachamanetin"-type compound $\mathbf{3 1}$ from Xylopia africana [34,35]. It has been postulated that the flavonoidal C-hydroxybenzyl group is biosynthetically derived from shikimic acid via the arene oxide shown in Scheme 1, followed by aromatization and deoxygenation [18]. 
<smiles>[R]c1c(O)c([R])c(OC)c(C(=O)CCc2ccccc2)c1O</smiles>

$$
\mathrm{R}
$$

19

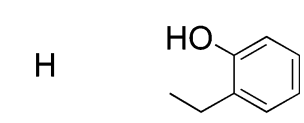

20: $\mathrm{HO}$

21:<smiles>COc1c(Cc2cc(Cc3ccccc3O)ccc2O)c(O)c(Cc2ccccc2O)c(O)c1C(=O)CCc1ccccc1</smiles>

24<smiles>[R]c1c([R])c2c(c(O)c1O)C(=O)C[C@H](c1ccccc1)O2</smiles>

$$
\mathrm{R}
$$

\section{$\mathrm{R}^{\prime}$}

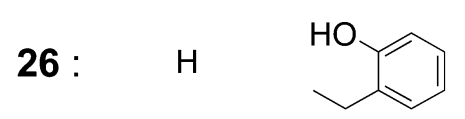

27: $\mathrm{HO}$<smiles></smiles><smiles>O=C(CCc1ccccc1)c1c(O)cc2c(c1O)Cc1c(O)cccc1O2</smiles>

22<smiles>COc1cc(O)c(Cc2ccccc2O)c(O)c1C(=O)CCc1ccccc1</smiles>

23<smiles>COc1c(Cc2ccccc2O)c(O)cc(O)c1C(=O)CCc1ccccc1</smiles>

25<smiles>O=C1C[C@H](c2ccccc2)Oc2c(Cc3ccccc3O)c(O)c(Cc3cc(Cc4ccccc4O)ccc3O)c(O)c21</smiles>

29

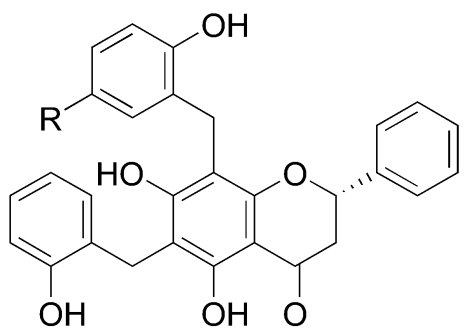

30: $\mathrm{R}=\mathrm{H}$

$31: R=$ 
Condensed chalcones having one chalcone unit coupled to either another chalcone moiety as in dependensin (32) [9], or to a monoterpene unit as in schefflerin (33), and isoschefflerin (34) [36], have been isolated from Tanzanian Annonaceae species as racemic mixtures. The schefflerins were considered to be products of a Diels-Alder-type cycloaddition reaction of the corresponding chalcone and the monoterpene $\beta$-ocimene, as shown by the formation of fragment ions corresponding to retro Diels-Alder fragmentation in the MS of $\mathbf{3 3}$ and $\mathbf{3 4}$ [36]. Moreover, the racemic nature of schefflerin and isoschefflerin would be a result of a nonenzymatic, spontaneous cycloaddition reaction for the formation of these compounds, as it is briefly discussed later in this article.<smiles>COc1cc(OC)c2c(c1OC)O[C@H]1c3c(OC)cc(OC)c(OC)c3O[C@@H](c3ccccc3)[C@H]1[C@H]2/C=C/c1ccccc1</smiles>

32<smiles>COc1cc(O)c(C(=O)[C@@H]2[C@H](C=C(C)C)C(C)=CC[C@@H]2c2ccccc2)c(O)c1OC</smiles>

33<smiles>COc1cc(O)c(C(=O)[C@@H]2CC=C(C)[C@H](CC=C(C)C)[C@H]2c2ccccc2)c(O)c1OC</smiles>

34<smiles>COc1cc(OC)c(OC)c(O)c1/C=C/C(=O)c1ccccc1</smiles>

35<smiles>COc1cc(OC)c(OC)c2c1C=CC(c1ccccc1)O2</smiles>

36

Until recently, chalcones whose carbonyl unit is adjacent to the unsubstituted ring B (the reversed chalcones) were not known among naturally occurring flavonoids. Thus, the first natural reversed chalcone 35 was isolated from the root and stem barks of Uvaria dependens [9]. Initially, compound 35 was considered to be an artifact, resulting from the decomposition of flavene $\mathbf{3 6}$ under the acidic isolation conditions. Indeed, when exposed to moist air, compound 36 was transformed into the reversed chalcone 35 [9]. However, both compounds 35 and $\mathbf{3 6}$ were detected even in fresh plant materials. This indicated that the two compounds coexisted in the natural environment, however, the latter compound being easily convertible into the former.

\section{Terpenoids}

In 1986, Prof. Waterman et al., then at the University of Strathclyde in Scotland, reported the isolation of three benzopyranyl sesquiterpenes that were named uvarisesquiterpene A-C [37]. Immediately afterwards, we isolated similar compounds from Tanzanian Uvaria species, however, with modified structural frameworks. Among these compounds were the spiro and bis benzopyranyl sesquiterpenes tanzanene (37) and lucidene (38) [32,38]. It was postulated that the sesquiterpenoids would be formed as products of conceivable Diels-Alder cycloaddition reactions involving an ortho-quinonemethide as the diene precursor and the corresponding sesquiterpene moiety as the dienophile. Lucidene was isolated 
as a racemic mixture and hence indicating that the biosynthesis of this compound would probably involve a nonenzymatic (Diels-Alder cycloaddition) reaction [38]. However, it was intriguing to note that the other benzopyranyl sesquiterpene tanzanene was obtained as an optically pure compound [32], thus indicating the participation of enzymes in its biosynthesis. As it will be briefly discussed later in this article, indeed enzymes have now been implicated to take place in Diels-Alder-type cycloaddition reactions in the biosynthesis of natural products.<smiles></smiles>

37<smiles>COC1=C(C(C)C)C(=O)[C@H]2Cc3cc(OC)c(C(C)C)c(OC)c3O[C@]2(C)C1=O</smiles>

40<smiles>C[C@H]1Oc2ccccc2C[C@@]1(C)CC[C@]1(C)Oc2ccccc2C[C@@]1(C)CC(C)(C)C</smiles>

38<smiles>COc1cc(C)c(O)c(OC)c1C(C)C</smiles>

39<smiles>COC1=C(C(C)C)C23Oc4c(cc(OC)c(C(C)C)c4OC)CC2C2(CCc4cc(OC)c(C(C)C)c(OC)c4O2)CC1=C(C(C)C)C3=O</smiles>

41

During our recent investigations, the highly oxygenated, antiprotozoal monoterpenoid espintanol (39) was obtained from Uvaria scheffleri (Annonaceae), together with compound $\mathbf{4 0}$ and schefflone (41) as the envisaged dimeric and trimeric products of 39, respectively [39,40]. Again, the two compounds $\mathbf{4 0}$ and $\mathbf{4 1}$ have been postulated as being products of the possible Diels-Alder-type cycloaddition reactions involving a quinone methide derivative of espintanol, i.e., 3-isopropyl-2,4-dimethoxy-6methylene-cyclohexa-2,4-dienone. Both compound $\mathbf{4 0}$ and schefflone were obtained as racemates $[39,40]$, this indicating the possible formation of these compounds through spontaneous and possibly nonenzymatic reactions. The cis-fused rings in compound $\mathbf{4 0}$ suggested a syn (Diels-Alder-type) cycloaddition process for the formation of this compound, involving the corresponding quinone methide as the precursor molecule.

From the root bark of the East African medicinal plant Hugonia castaneifolia (Linaceae), we isolated the rosane diterpenoids hugorosenone (42), 18-hydroxyhugorosenone (43), and hugorosediol (44), together with the bis 15,16-dinor-pimaranoids hugonone A (45) and hugonone B (46) [41]. The structural framework of the hugonones relates to these compounds having been derived through an enzymatic coupling of two molecules of a nor-pimaranoid, since the hugonones were obtained in their optically pure forms. ${ }^{1} \mathrm{H}$ NMR studies (NOE and coupling constants) indicated the endo-orientation and syn-addition of the two monomeric nor-pimaranoid units in the hugonones A and B [41]. 
<smiles>C=C[C@H]1CC[C@]2(C)C3=CC(=O)[C@@H](O)C(C)(C)C3CC[C@H]2C1</smiles>

42<smiles>C=C[C@]1(C)CC[C@]2(C)C3=CC(=O)[C@@H](O)[C@@H](CO)[C@H]3CC[C@H]2C1</smiles>

43<smiles>C=C[C@]1(C)CC[C@]2(C)C3=CC[C@@H](O)[C@H](C)[C@H]3CC[C@H]2C1</smiles>

44

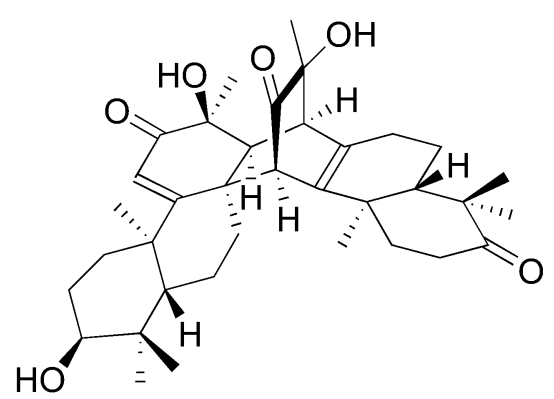

45

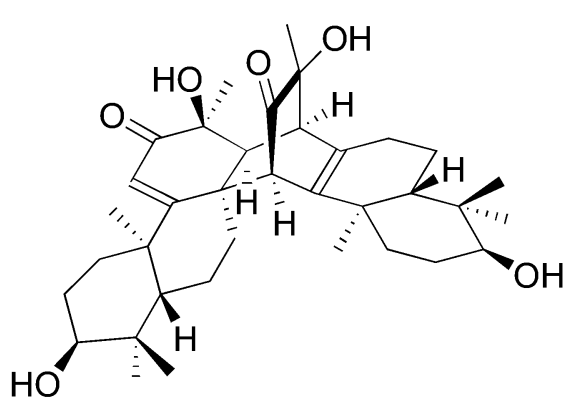

46

\section{Prenylated indoles}

Prenylated indoles are fairly common constituents of the family Annonaceae, although these compounds have also been found in the family Rutaceae [42-44] as well as in riverworts [45]. These compounds have been isolated from the Annonaceae genera Annonidium [46], Asteranthe [47], Hexalobus [48], Isolona [49-51], Monodora [51], and Uvaria [52]. They consist of mono- and bis-prenylated isomers, as well as dimeric bis-prenylated indoles, some of the compounds having interesting antifungal and other biological activities. Thus, two antimycotic diprenylated indoles $\mathbf{4 7}$ and $\mathbf{4 8}$, which are structurally similar to the hexalobines, but one of the prenyl groups forming a pyranoid ring fused to the indole moiety, were recently isolated from the two Tanzanian Asteranthe species, A. asterias and A. lutea (Annonaceae) $[11,47]$. The compounds, which are first examples of naturally occurring pyranoindoles, were isolated as enantiomeric mixtures consisting of $S$ and $R$ enantiomers in the ratio 3:1, as determined by HPLC separation of hydrogenated derivatives using a chiral sorbent (Chiracel® OD), and the CD<smiles>CC1(C)C=Cc2ccc3c(CC4OC4(C)C)c[nH]c3c2O1</smiles>

47<smiles>CC(=O)/C=C/c1ccc2cc[nH]c2c1</smiles>

49<smiles>CC1(C)C=Cc2ccc3c(CC(O)C(C)(C)O)c[nH]c3c2O1</smiles>

48<smiles>CC(C)=CCc1ccc2c(c1)NC(=O)C2</smiles>

51 
curves of pure hydrogenated enantiomers being compared with the $\mathrm{CD}$ spectra of dihydro-hexalobine $\mathrm{B}$, whose absolute configuration at the chiral center was known [47].

We recently isolated indole 49, which has a partially degraded prenyl unit, 5-formylindole (50), and the prenylated indolactam 51 from Monodora angolensis [51], compound 49 having been previously obtained as an intermediate toward the synthesis of the antifungal and antibacterial indoles 6-(3-methyl-2-butenyl)-1 $H$-indole and 6-(3-methylbuta-1,3-dienyl)-1 $H$-indole.<smiles>C=CC(C)(C)c1c[nH]c2ccc(CC=C(C)C)cc12</smiles>

52<smiles>C=CC(C)(C)c1c[nH]c2ccc(/C=C/C(C)=O)cc12</smiles>

53<smiles>C=CC(C)(C)c1c[nH]c2ccc(C=O)cc12</smiles>

54

Prenylated indole alkaloids form the largest group of natural products found in the genus Isolona, whereby all the monoprenylated indoles contain a C-5 prenyl group, while in the diprenylated indoles the latter group is attached at indolyl C-3 and C-5, or C-3 and C-6. Diprenylated indoles that are collectively referred to as the hexalobines have been isolated from I. maitlandii as isomeric pairs [49], the compounds for the first time having been isolated from Hexalobus species (Annonaceae) [48]. From I. cauliflora, we recently isolated the bis-prenylated indole caulidine A (52), the partially oxidized bis-prenylated indole caulidine B (53) and the prenylated formylindole 54, and four dimeric prenyl indoles that occurred as diastereomeric pairs, namely, the caulindole A-D (55-58), some of which exhibited antifungal activity [50].

The diastereomeric caulindoles A (55) and B (56) were distinguishable based on ${ }^{1} \mathrm{H}$ NMR signals for H-3, H-7, and $\mathrm{H}-10$ as well as the corresponding ${ }^{13} \mathrm{C}$ NMR resonances for C-3/C-7 and C-10. Thus, caulindole A with a transoid geometry at C-3/C-4 exhibited ${ }^{1} \mathrm{H}$ NMR signals for $\mathrm{H}-3$, H-7, and $\mathrm{H}-10$ at $\delta 3.50,6.32$, and 0.82 , respectively, whereas for caulindole $\mathrm{B}$ that has a cisoid geometry at $\mathrm{C}-3 / \mathrm{C}-4$, the signals for $\mathrm{H}-3, \mathrm{H}-7$, and $\mathrm{H}-10$ occurred at $\delta 3.36,6.12$, and 1.20 , respectively. Likewise in the ${ }^{13} \mathrm{C}$ NMR spectrum, the signals for C-3, C-7, and C-10 for compound $\mathbf{5 4}$ appeared at $\delta 51.70$, 138.40 , and 21.56 while for caulindole B the signals occurred at $\delta 53.44,135.22$, and 25.50, respectively. This distinction also applied to the diastereomeric caulindole $\mathrm{C}(\mathbf{5 7})$ and caulindole D (58). These<smiles>CC1=CC(=O)C(C)(c2ccc3[nH]ccc3c2)CC1</smiles><smiles>C=CC(C)(C)c1c[nH]c2ccc(/C=C/[C@@]3(C)CCC(C)=C[C@H]3c3ccc4[nH]cc(C(C)(C)C=C)c4c3)cc12</smiles><smiles>CC1=C[C@H](c2ccc3[nH]ccc3c2)[C@H](C)CC1</smiles><smiles>C=CC(C)(C)c1c[nH]c2ccc(C=C[C@]3(C)CCC(C)=C[C@H]3c3ccc4[nH]cc(C(C)(C)C=C)c4c3)cc12</smiles> 
spectral differences can be explained based on stereochemical considerations and the corresponding electronic effects of the substituents.

The caulindoles can be perceived as products of Diels-Alder-type cycloaddition reactions between the presumed monomeric prenyled indoles acting as the diene and dienophile [50]. Apparently, the regiochemistry of the caulindoles indicates that biosynthetically these compounds would indeed have been formed through Diels-Alder-type cycloaddition reactions involving simpler prenylated indoles as dienes and dienophiles, in accordance with Frontier Orbital Theory (FOT) predictions [53].

Molecular models of the caulindoles showed that suitable orbital interactions would exist between the double bonds in the corresponding dienophile and diene, thereby favoring the endo approach of the dienophile and diene. However, it is interesting to note that both the exo (caulindole A and caulindole C) and endo products (caulindole B and caulindole D) were obtained from I. cauliflora in nearly the same proportions [50]. This and the fact that caulindole $\mathrm{A}$ was obtained as an optically active compound $\left([\alpha] \mathrm{D}=+13.95^{\circ}, \mathrm{c}=0.17, \mathrm{CHCl}_{3}\right)$ complicates further the presumed biosynthesis of caulindoles. The nonregioselective nature of the biosynthesis of the caulindoles is probably a result of reaction phenomena other than effects predicted from the FOT, including enzymatic processes, as briefly discussed in the following section.

\section{Natural products biosynthesis through conceivable Diels-Alder cycloaddition}

Whether the conceived formation of natural products through Diels-Alder-type cycloaddition reactions are enzymatic or not is still a subject of much debate. The inherent spontaneous and thus nonstereoselective nature of Diels-Alder cycloaddition reactions entails that racemic natural products would always be formed in such biosynthetic processes, unless enzymes are also involved. However, several natural products that would otherwise be biosynthetically obtained through Diels-Alder-type cycloaddition reactions have been obtained in optically pure forms as well [e.g., tanzanene (37)] [32]. It is also interesting to note that optically impure, nonracemic natural products have also been isolated from plants, e.g., 2',3'-epoxyasteranthine (47), which was recently obtained from Asteranthe asterias and A. lutea (Annonaceae) [11,47]. This indicates the possible participation of enzymes even in these otherwise spontaneous biosynthetic reactions. Indeed, there is currently circumstantial evidence that might explain the existence of a special enzyme strain called "dielsalderase" that would catalyze the formation of natural products through Diels-Alder-type cycloaddition reactions [54].

\section{CONCLUSION}

This article summarizes reported findings on investigations for natural products from Tanzanian indigenous plant species as carried out at the University of Dar es Salaam over the past 20 years. Indeed, within this time frame a number of compounds with unusual chemical structures were isolated and characterized as indicated in this article. Similarly, several new plant species have been taxonomically described. Some of these plant species have been a subject of our investigations, whereby they have actually been among the interesting sources of secondary metabolites having quite unusual chemical structures. As it is, there seems still to be quite a number of plant species awaiting scientific identification in our virgin forests. Therefore, it can be envisioned that these plant resources, once taxonomically identified, will form an interesting source of novel natural products with unusual chemical structures.

\section{ACKNOWLEDGMENTS}

The investigations that we have carried out over the past 20 years were funded by various organizations, including the Norwegian Agency for International Development (NORAD), the International Foundation for Science (IFS), the Netherlands Organization for International Cooperation in Higher 
Education (NUFFIC), Sida/SAREC of Sweden, and the University of Dar es Salaam. These institutions are sincerely acknowledged for supporting our research. I also wish to extend my sincere appreciations to my coworkers whose names appear in our various publications as cited in this article as references, and Prof. Berhanu M. Abegaz of the University of Botswana for facilitating spectral analysis of our compounds using equipment at his University, through NABSA.

\section{REFERENCES}

1. J. P. M. Brenan. Ann. Missouri Bot. Gard. 65, 437-478 (1978).

2. K. Vollesen. Opera Bot. 59, 1-117 (1980).

3. B. Verdcourt. Kew Bull. 41, 287-297 (1986).

4. B. Vercourt and L. B. Mwasumbi. Kew Bull. 43, 99-101 (1988).

5. B. Verdcourt. Garcia de Orta, Ser. Bot. 13, 43-48 (1996).

6. D. M. Johnson, L. B. Mwasumbi, F. M. Mbago. Novon 9, 55-60 (1999).

7. R. Hollands, D. Becher, A. Gaudemer, J. Polonsky. Tetrahedron 24, 1633-1650 (1968).

8. M. H. H. Nkunya, H. Weenen, N. J. Koyi, L. Thijs, B. Zwanenburg. Phytochemistry 26, 2563-2566 (1987).

9. M. H. H. Nkunya, R. Waibel, H. Achenbach. Phytochemistry 34, 853-856 (1993).

10. G. Y. Liang, A. I. Gray, D. W. Thomas, P. G. Waterman. Phytochemistry 27, 3857-3860 (1988).

11. J. J. Magadula. M.Sc. Thesis, University of Dar es Salaam, Tanzania (2000).

12. S. Samwel. M.Sc. Thesis, University of Dar es Salaam, Tanzania (2003).

13. P. Tuntiwachwuttikul, O. Pancharoen, W. A. Bubb, T. W. Hambley, W. C. Taylor, V. Reutrakul. Aust. J. Chem. 40, 2049-2061 (1987).

14. S. M. Kupchan, R. J. Hemingway, R. M. Smith. J. Org. Chem. 34, 3898-3902 (1969).

15. A. N. Sawhney, M. R. Khan, G. Ndaalio, M. H. H. Nkunya, H. Wevers. Pakistan J. Sci. Ind. Res. 21, 189-194 (1978).

16. M. H. H. Nkunya, H. Weenen, D. H. Bray, Q. A. Mgani, L. B. Mwasumbi. Planta Med. 57, 341-343 (1991).

17. G. R. Schulte and B. Ganem. Tetrahedron Lett. 23, 4299-4302 (1982).

18. B. Ganem and G. W. Holbert. Bioorg. Chem. 6, 393-396 (1977).

19. C. Mahidol. Ciba Foundation Symp. Ser. 154, 66 (1990).

20. G. R. Schulte, M. Kodpinid, C. Thebtaranonth, Y. Thebtaranonth. Tetrahedron Lett. 23, 4303-4304 (1982).

21. M. Höhn. Ph.D. Thesis, University of Erlangen - Nürnberg, Germany (1998).

22. S. Ogawa and T. Takagaki. J. Org. Chem. 50, 2356-2359 (1985).

23. A. Ichihara, K. Oda, M. Kobayashi, S. Sakamura. Tetrahedron 36, 183-188 (1980).

24. H. J. Jung, C.-J. Chang, D. L. Smith, J. L. McLaughlin. J. Nat. Prod. 54, 500-505 (1991).

25. P. Tuchida, J. Udchachon, V. Reutrakul, J. Santisuk, W. C. Taylor, N. R. Farnsworth, J. M. Pezzuto, A. D. Kinghorn. Phytochemistry 30, 2685-2689 (1991).

26. S. W. Momburi. M.Sc. Thesis, University of Dar es Salaam, Tanzania (1998).

27. J. H. Jung, C. J. Chang, J. L. McLaughlin, S. Pumangura, C. Chaichantipyuth, P. E. Patarapanich, P. E. Fanwich. Tetrahedron 46, 5043-5054 (1990).

28. B. N. Irungu. M.Sc. Thesis, University of Dar es Salaam, Tanzania (2001).

29. H. Mrema. M.Sc. Dissertation, University of Dar es Salaam, Tanzania (2001).

30. H. Achenbach, M. Höhn, R. Waibel, M. H. H. Nkunya, S. A. Jonker, S. Muhie. Phytochemistry 44, 359-364 (1997).

31. J. J. Makangara, S. A. Jonker, M. H. H. Nkunya. Nat. Prod. Lett. 16, 267-272 (2002).

32. H. Weenen, M. H. H. Nkunya, Q. A. Mgani, M. A. Posthumus, R. Waibel, H. Achenbach. J. Org. Chem. 56, 5865-5867 (1991). 
33. M. H. H. Nkunya, H. Weenen, C. Renner, R. Waibel, H. Achenbach. Phytochemistry 32, 1297-1300 (1993).

34. E. M. Anam. Indian J. Chem. 33B, 204-205 (1994).

35. E. M. Anam. Indian J. Chem. 33B, 1009-1011 (1994).

36. M. H. H. Nkunya, H. Achenbach, C. Renner, R. Waibel, H. Weenen. Phytochemistry 29, 1261-1364 (1990).

37. I. Muhammad and P. G. Waterman. J. Nat. Prod. 51, 719-724 (1988).

38. H. Weenen, M. H. H. Nkunya, A. Abdul El-Fadl, S. Harkema, B. Zwanenburg. J. Org. Chem. 55, 5107-5109 (1990).

39. C. Kihampa. M.Sc. Thesis, University of Dar es Salaam, Tanzania (2002).

40. M. H. H. Nkunya, S. A. Jonker, R. de Gelder, S. W. Wachira, C. Kihampa. Phytochemistry 65, 399-404 (2004).

41. L. K. Mdee, R. Waibel, M. H. H. Nkunya, S. A. Jonker, H. Achenbach. Phytochemistry 49, 1107-1113 (1998).

42. T. Kinoshita, S. Tatara, U. Sankawa. Chem. Pharm. Bull. 33, 1770-1773 (1985).

43. M. H. Abu Zarga. J. Nat. Prod. 49, 901-904 (1986).

44. F. D. Monache, G. D. Monache, M. A. De Moraes e Souza, M. Da Salete Cavalacanti, A. Chiapetta. Gazz. Chim. Ital. 119, 435-439 (1989).

45. V. Benesová, Z. Samek, V. Herout, F. Sorm. Collect. Czech. Chem. Commun. 34, 1807-1809 (1969).

46. H. Achenbach and C. Renner. Heterocycles 23, 2075-2081 (1985).

47. M. H. H. Nkunya, S. A. Jonker, L. K. Mdee, R. Waibel, H. Achenbach. Nat. Prod. Lett. 9, 71-78 (1996).

48. H. Achenbach, C. Renner, R. Waibel. Liebigs Ann. Chem. 1327-1337 (1995).

49. H. Achenbach and M. Löwell. Phytochemistry 40, 967-973 (1995).

50. J. J. Makangara, L. Henry, S. A. Stephan, M. H. H. Nkunya. Phytochemistry 65, 227-232 (2004).

51. M. H. H. Nkunya, J. J. Makangara, S. A. Jonker. Nat. Prod. Res. 18, 253-258 (2004).

52. H. Achenbach and B. Raffelsberger. Tetrahedron Lett. 28, 2571-2574 (1979).

53. I. Fleming. Frontier Orbitals and Organic Chemical Reactions, John Wiley, Chichester (1976).

54. J. F. Sanz-Gervera, T. Glinka, R. M. William. J. Am. Chem. Soc. 115, 347-348 (1993). 